\title{
The institutionalization of Habsburg-Dutch border controls during the Eighty Years War
}

\author{
La institucionalización de los controles fronterizos entre los territorios \\ Habsbúrgicos y holandeses durante la guerra de los ochenta años
}

\section{Bram De Ridder}

University of Leuven

\begin{abstract}
This article discusses the origins and institutionalization of border controls during the Eighty Years War in the Low Countries (ca. 1568-1648). The HabsburgDutch border that was created during this conflict was a brand new territorial separation, stemming from the secession of the Dutch Republic from the wider Habsburg Empire. The novelty of this border meant that already during the war the two governments needed to be creative in their handling of it and that they needed to develop several new strategies of border management. These strategies for controlling the border were however not developed as part of a centralized program of state formation. Rather, the two governments in Brussels/Madrid and The Hague engaged in a process of learning that involved many other actors as well. By looking into three specific types of such interaction, this article illustrates the learning process that accompanied the installation of systems for passage control in the HabsburgDutch borderlands.
\end{abstract}

Key words: Institutionalization; borders; border management; Eighty Years War

Resumen: El artículo analiza la formación de la frontera entre los Habsburgo y los Países Bajos entre aproximadamente 1572 y 1648 . Este límite se formó durante la Guerra de los Ochenta Años entre la dinastía de los Habsburgo y la República seccionalista de las Provincias Unidas, separando la República de los territorios restantes de los Países Bajos Habsburgo. Por lo tanto, la frontera cuenta como una notable innovación territorial, que rápidamente requirió la institucionalización de todo tipo de medidas para controlar la frontera. Dicha institucionalización tomó muchas formas diferentes durante (y después) de la Guerra, pero tres modos pueden ser considerados muy importantes: la necesidad de responder al enemigo a través de la frontera, las sugerencias de los sujetos in situ y las discusiones con tales sujetos y otros subordinados. La importancia de estos elementos revela que la institucionalización de la nueva frontera seguramente no era un asunto centrado del Estado o patrocinado por el Estado, sino que dependía de las variadas interacciones entre varios actores. 


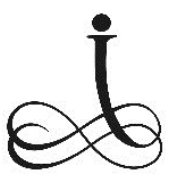

$\mathrm{n}$ most of the available historiography, early modern wars are associated with large-scale death and destruction. ${ }^{1}$ But in certain cases they are also connected to the genesis of new technologies, new ideas, new governments and even new countries. This for example applies to the Eighty Years War (ca. 1668-1648), a war that counts as one of the most vicious, destructive and long-lasting of the early modern period. Yet, this war is also associated with the start of a period of growth and renewal. Out of the Eighty Years War there namely emerged a brand new country -The Dutch Republic of United Provinces - with a unique type of government, a new fiscalmilitary system and a new global role. As a result, the details of how the Dutch Republic seceded from the Spanish-Habsburg Empire and how this resulted in all sorts of political, religious, economic and cultural novelties have been extremely well-studied. ${ }^{2}$ Yet, one specific 'innovation' that accompanied the war has largely been overlooked in the studies concerning the HabsburgDutch conflict. The fact that the United Provinces successfully seceded from the Habsburg-controlled provinces in the Low Countries also meant that a new border was created between the Dutch Republic and the remaining Habsburg Netherlands. Due to the violent and chaotic nature of the war this boundary had no real precedent, meaning that both its territorial and administrative aspects were experienced as clear novelties. Logically, this begs the question as to how exactly the Eighty Years War shaped the Habsburg-Dutch border.

In this article I will provide part of the answer to this question by discussing a number of elements that contributed to the institutionalization of the new border. What this means is that I will look into how certain territorial practices helped shape the boundary and how they gave it a recognizable 'form'. This form should be strictly interpreted in a legal and administrative way: I will not discuss the exact geographical location of the border, i.e. explain which military campaigns resulted in which territorial losses or gains for a particular side. This latter aspect has been sufficiently discussed in many of the general oversights of the Eighty Years War and adds little to our understanding of what the new border meant to contemporaries. ${ }^{3}$ Instead, I will focus on the practices involving legal and administrative border controls. How exactly was

\footnotetext{
1 This article has been written as part of the doctoral project 'Lawful Limits: Border Management and the formation of the Habsburg-Dutch Boundary', finished in November 2016 at the University of Leuven.

2 For two oversights, see Jonathan I. Israel, The Dutch Republic. Its Rise, Greatness, and Fall 1477-1806, (Oxford: Clarendon Press, 1995); Maarten Prak, The Dutch Republic in the Seventeenth Century: The Golden Age, (Cambridge: University Press, 2005).

${ }^{3}$ See for example Israel, The Dutch Republic; Ronald De Graaf, Oorlog, mijn arme schapen. Een andere kijk op de Tachtigjarige Oorlog 1565-1648, (Franeker: Van Wijnen, 2004).
} 
the territorial border made real to those who wanted to cross the separation, and how did these practices go from ad hoc war-time controls to an administrative system that continued to play a role even after the war had ended? ${ }^{4}$. Given the fact that discussing this entire process would lead us too far, I will focus on three specific influences: the need to respond to enemy actions, the role of suggestions from subjects, and discussions with subjects and other subordinates about the requirements for crossing the border. Importantly, and as this article will show, these cases demonstrate that the institutionalization of the Habsburg-Dutch border cannot be understood through the lens of one-sided nation or state formation but needs to be seen as the chaotic interplay of challenges and responses stemming from all sorts of different actors - including several coming from across the border itself.

\section{The origins of a system of border controls}

\section{The 'licenten en convoyen' as starting point}

The starting point for the Habsburg-Dutch border controls can be found in the earlier decades of the Eighty Years War, right around the time the conflict turned from a revolt and civil war into a secessionist conflict between the Habsburg Empire and the gradually better organised United Provinces. At first, these controls centred around preventing cross-border trade, with a specific focus on strategic goods such as horses, weapons, ammunition and supplies. Economically strangling your enemy was (and is) a well-known strategy in times of political conflict and likewise represented one of the foremost military strategies during the Eighty Years War. The Spanish Habsburgs and the Dutch Republic frequently instigated commercial embargoes against one another and increasingly monitored and regulated all commercial traffic between them. ${ }^{5}$ But because completely stopping trade had a serious negative effect on their own economies and public finances, both governments usually loosened their blockades by setting up a system of

\footnotetext{
${ }^{4}$ For eighteenth-century developments that followed out of this growing system, see for example P. Moureaux, "Un organe peu connu du gouvernement des Pays-Bas autrichiens: le Bureau de régie des droits d'entrée et de sortie", Belgisch Tijdschrift voor Filologie en Geschiedenis/ Revue Belge de Philologie et Histoire 44, (1966), pp. 479-499; Michel Dorban, ed., Douane, commerce et fraude dans le sud de l'espace Belge et Grand-Ducal au XVIIIe siècle. Travaux d'étudiants synthétisés par Christien Piraux, (Louvain-la-Neuve: BruylantAcademia, 1998).

${ }^{5}$ See primarily Victor Enthoven, Zeeland en de opkomst van de Republiek. Handel en strijd in de Scheldedelta, c. 1550-1621, (Leiden: Luctor et victor, 1996), pp. 109-110; Jonathan I. Israel, Empires and Entrepots. The Dutch, the Spanish Monarchy and the Jews, 1585-1713, (London, Ronceverte: The Hambledon Press, 1990); Jonathan I. Israel, "España, los embargos españoles y la lucha por el dominio del comercio mundial, 1585-1648", Revista de Historia Naval 23, (1988), pp. 89-105; Jonathan I. Israel, Dutch Primacy in World Trade, 1585-1740, (Oxford: Clarendon Press, 1989); Eddy Stols, De Spaanse Brabanders of de handelsbetrekkingen der zuidelijke Nederlanden met de Iberische Wereld, 1598-1609, (Brussels: Koninklijke Vlaamse Academie voor Wetenschappen, Letteren en Schone Kunsten van België, 1971).
} 
licensed exemptions called the "passports for goods", better known in the Republic under the notion of licenten and convoyen (the former applying to trade with the enemy, the later to trade with neutrals). ${ }^{6}$

At its core the system of passports for goods determined that in return for declaring their wares and paying so-called licentgeld -a fee of which the price was determined according to detailed customs lists- merchants received a licentbrief, a signed letter which provided legal proof that the permit had been paid and that the stated merchandize could be im- or exported. Regulating cross-border trade through paid permits was certainly not new in the Netherlands: long before the Dutch Revolt specific tolls had been levied on the trade over land or by river. ${ }^{7}$ However, during the Eighty Years War the expanding licenten-system came to complement these older taxes, with the County of Zeeland being at the forefront of developments.

Immediately after the conquest of Den Briel in 1572 the insurgent authorities in this province instigated a naval blockade of Antwerp, a measure that was so successful that it completely halted the Scheldt trade by following June. ${ }^{8}$ But such an effective blockade also entailed a serious financial burden. In order to pay for its upkeep the revolting Zeeland towns introduced the licenten, allowing mercantile goods to pass the blockade as long as the traders paid the mentioned licentgeld. In October 1572 this system was jointly adopted by all of the revolting city magistrates in Zeeland and by 1573 William of Orange introduced it in Holland. Not even a year later the system was again expanded and refined, as a new placard subjected all of Zeeland's trade with the enemy and with neutral countries to the payment of licentgeld and furnished the Scheldt and the Flemish ports with a blockade of around fifty wachtschepen ['waiting ships'], ${ }^{9}$ a number that by 1596 increased to sixty-eight ships for Flanders alone. ${ }^{10}$ From there on allowing licensed trade

\footnotetext{
${ }^{6}$ F.H.M. Grapperhaus, Convoyen en licenten, (Zutphen, Deventer: De Walburg Pers/Kluwer, 1986), p. 16.

7 Daniel Gheret, "Le produit des licences et autres impôts sur le commerce extérieur dans les Pays-Bas espagnols (1585-1621)", in Recherches sur I'histoire des finances publiques en Belgique, Tome II, Acta Historica Bruxellencia 2, eds. M.-A. Arnould, J. Craeybeckx and H. Hasquin, (Brussels: Institut d'histoire de l'Université Libre de Bruxelles, 1970), pp. 43-46; Enthoven, Zeeland en de opkomst, p. 9; Leo Adriaenssen, Staatsvormend geweld. Overleven aan de frontlinies in de meierij van Den Bosch, 1572-1629, (Tilburg: Stiching Zuidelijk Historisch Contact, 2007), p. 50. For an overview of the tolls on Rhine, Meuse and Waal and their origins, see W.F. Leemans, De grote Gelderse tollen en de tollenaars in de 18e en het begin der 19de eeuw. Een bijdrage tot de geschiedenis van de Rijnhandel, (Arnhem: De Walburg Pers, 1981), pp. 7-9, 12-13.

8 Enthoven, Zeeland en de opkomst, p. 38; Victor Enthoven, "De ondergang van de Nederlandse handelssuprematie. Fiscale maatregelen en maritieme machtsmiddelen in de $17^{\text {de }}$ eeuw", in De Republiek tussen zee en vasteland. Buitenlandse invloeden op cultuur, economie en politiek in Nederland, 1580-1800, eds. Karel Davids, Marjolein 't Hart, Henk Kleijer and Jan Lucassen, (Leuven, Apeldoorn: Garant, 1995), p. 250.

9 Enthoven, Zeeland en de opkomst, pp. 38-41, 52-53; J.H. Kernkamp, De handel op den vijand, 1572-1609, Vol. 1, (Utrecht, 1931), pp. 20-21; Grapperhaus, Convoyen, pp. 15-16; Bindoff, Stanley, The Scheldt Question to 1839, (London: George Allen \& Unwin, 1945), pp. 82-87.

10 Michiel de Jong, Staat van oorlog: wapenbedrijf en militaire hervorming in de republiek der Verenigde Nederlanden, 1585 - 1621, (Hilversum: Verloren, 2005), p. 60.
} 
became a key part of Dutch border management, punctuated only by limited moments of 'hard' embargoes and by the brief period the Pacification of Ghent restored free trade in the Low Countries. ${ }^{11}$ Crucially, this new system also contributed significantly to the development of the Dutch public finances: Marjolein't Hart stressed that during the Eighty Years War about twelve percent of the Republic's generale middelen [general budget] derived from the licenten and convoyen. ${ }^{12}$

The practical administration of such an expanding system quickly required further physical and legal adaptations. In 1586 the newly created Dutch Admiralties were charged with issuing and collecting the licenten, be it at sea, on the rivers or on land. They were at the same time entitled to re-invest the collected money in their own activities, theoretically making Dutch passage control a self-paying enterprise and giving the Admiralties a strong incentive to argue against full-on embargoes (the so-called 'closing of licenten'). ${ }^{13}$ Soon enough the United Provinces opened licentkantoren [licence-offices] in the fortresses of Lillo and Philippine (1589), followed by similar offices in the towns of Veere, Vlissingen, Middelburg and Arnemuiden (1589), Ter Hofstede (1592), Bergen op Zoom (1593), Mauritsfort (1605), Ijzendijke (1608) and Aardenburg and Sluis (1609). ${ }^{14}$ Moreover, by 1594 in Lillo alone almost 300 independent boatmen worked to practically arrange the obligatory verbodemen [transshipping, the transfer of goods and passengers from a Dutch ship to a Habsburg one and vice-versa] of commercial goods that were transported over the river Scheldt. ${ }^{15}$

On the Habsburg side the first trade bans were introduced between 1574 and 1580 and here also a system of licensed trade was quickly established. ${ }^{16}$ Attesting to the importance Philip II and his successors awarded to passage control, from early on all Habsburg soldiers were entitled to randomly inspect vessels and the officers of the frontier fortresses were instructed to make sure that no illegal goods entered or left the country. ${ }^{17}$ Shifting the focus from

\footnotetext{
11 Enthoven, Zeeland en de opkomst, pp. 44-55; Bindoff, The Scheldt Question, pp. 88-89.

12 Marjolein 't Hart, The making of a bourgeois state: war, politics and finance during the Dutch revolt, (Manchester: Manchester University Press, 1993), p. 86; Marjolein 't Hart, "The merits of a financial revolution: public finance, 1550-1700", in A Financial history of The Netherlands, eds. Marjolein 't Hart, Joost Jonker and Jan Luiten van Zanden, (Cambridge: Cambridge University Press, 1996), pp. 22-27; H.L. Zwitser, "Het quotenstelsel onder de Republiek der Verenigde Nederlanden", Mededelingen van de Sectie Militaire Geschiedenis Landmachtstaf 5, (1982), p. 6. More specific figures can be found in Enthoven, Zeeland en de opkomst, annex; Victor Enthoven, "Een duivels dilemma: Zeeland en de beheersing van de Schelde, 15721609", in De Scheldedelta als verbinding en scheiding tussen Noord en Zuid, 1500-1800, eds. Maurits Ebben and Simon Groenveld, (Maastricht: Shaker Publishing, 2007), p. 49.

13 Grapperhaus, Convoyen, pp. 26-27; Bindoff, The Scheldt Question, pp. 89-90.

14 Enthoven, Zeeland en de opkomst, pp. 119-120; Enthoven, "Een duivels dilemma", p. 37. For other examples linking fortresses to the control of trade, see Adriaenssen, Staatsvormend geweld, pp. 99, 102, and 113.

15 Enthoven, Zeeland en de opkomst, p. 110. For a short appraisal of the (dis)advantages of this practice, see Bindoff, The Scheldt Question, pp. 91-93.

16 Stols, De Spaanse Brabanders, p. 31.

17 Repetition of the ban on providing the enemy with food and supplies, 28/03/1579: Antonium Anselmo, Placcaeten, ordonnantien, landt-chartres, blyde-incomsten, privilegien, ende
} 
a military to a civil administration, several new laws prefigured the appointment of licentmeesters and so-called cherchers [inspectors, also called visiteerders or visitateurs], two civil offices respectively charged with the issuing of the actual paper licenten and the inspection of arriving and departing goods. ${ }^{18}$ These officers fell under the authority of the Council of Finances in Brussels, meaning that the money they collected was nominally a part of the ruler's overall income. Yet, as in the Republic the money was often directly spent on the defence of the region were it had been collected, sometimes even by the licentmeesters themselves. ${ }^{19}$ By 1593 at least fifteen autonomous licent-offices had opened in the Habsburg Netherlands, including in Antwerp and 's-Hertogenbosch in Brabant, Bruges and Dunkirk in Flanders, and Venlo and Roermond in Guelders. ${ }^{20}$ Numerous subordinate offices depended of these fifteen; the licentmeesters of 's-Hertogenbosch commanded officers in no less than a dozen other towns and fortresses in Brabant. ${ }^{21}$ Comparable to the United Provinces the money these controls generated also became a crucial source of revenue: Daniel Gheret calculated in 1970 that between 1593 and 1597 the licenten and passports for persons composed between forty and sixty-five percent of the total sums received by the Habsburg receiver-general in the Low Countries. ${ }^{22}$

\section{The changing physical landscape}

Trade over sea was of course not the only means of crossing from Habsburg territory into Dutch lands or vice-versa. The new borders on land - in times of war called frontieren - stretched from Cadzand in North-Western Flanders

instructien, by den Princen van dese Neder-landen aen de Inghesetenen van Brabandt, Vlaenderen, ende andere provincien, t'sedert t'Iaer M.CC.XX., Vol. 1, (Antwerp: Hendrick Aertssens, 1648), pp. 286-287; After 1621 the trade war of the Habsburg government became backed by the creation of a privateering base in Dunkirk, which severely hit Dutch fishing and trade: Virginia West Lunsford, Piracy and Privateering in the Golden Age Netherlands, (New York: Palgrave Macmillan, 2005), pp. 109-114; R.A. Stradling, "The Spanish Dunkirkers, 162148: A Record of Plunder and Destruction", Tijdschrift voor Geschiedenis 93, (1980), pp. 541558.

18 Ordinance regarding the equipment of trading ships, 05/08/1579: Jan Baptiste Christyn, Placcaeten, ordonnantien, landt-chartres, blyde-incomsten, privilegien, ende instructien, by den Princen van dese Neder-landen aen de Inghesetenen van Brabandt, Vlaenderen, ende andere provincien, t'sedert t'Iaer M.CC.XX., Vol. 3, (Brussels: Huybrecht Anthoon Velpius, 1664), pp. 232-240.

${ }_{19}$ Advice regarding the collection and spending of licenten on the river Demer, s.d: Algemeen Rijksarchief/Archives General du Royaume, Brussels (hereafter AGR), Conseil d'Etat, nr. 1592; Habsburg specification of sauvegarde and passport regulations, 20/08/1621: AGR Papiers d'Etat et de I'Audience, 1137/3 (3); Gheret, "Le produit", pp. 92-95.

20 The full list is found in Gheret, "Le produit", pp. 61, 97. However, he acknowledges that the archives of the Council of Finances did not allow him to track all Habsburg licent-offices.

${ }^{21}$ After the Truce this growth did not stop, as at least another six offices were opened along the Hasburg-Dutch border: Gheret, "Le produit", pp. 63-5. Moreover, in Spain itself new bodies were also created to regulate economic warfare, for example the Junta de Comercio of 1622 and the famous Almirantazgo de los Países Septentrionales of 1624. Jonathan I. Israel, "A conflict of Empires: Spain and the Netherlands, 1618-1648", in Israel, Empires and Entrepots, pp. 17-18. First printed in Past and Present 76, (1977), pp. 34-74.

22 Gheret, "Le produit", pp. 51-52, 65. 
to the city of Emden in East-Frisia, their actual shape being determined by the warring parties' victories and losses on the battlefield. Importantly, both early modern and modern historians stressed how the inhabitants of the frontiers had to live with constant danger. ${ }^{23}$ Especially during the earlier stages of the Eighty Years War the Habsburg-Dutch borderlands represented a space of constant insecurity. As Leo Adriaenssen highlighted for Brabant and Tim Piceu and Adriaan de Kraker for Flanders, during the war the populations of the Habsburg-Dutch borderlands fell victim to attacks by unruly and often underpaid soldiers, to state-sanctioned pillaging campaigns, and to all sorts of other violent measures initiated by people who wanted to maintain a claim over the frontiers and their revenue. ${ }^{24}$

The travellers who still needed or wanted to cross the frontier encountered much the same dangers. This is exemplified by the troubles of Guillaume du Terme, messenger for the city of Bruges, who between 1584 and 1609 was five times taken hostage by Dutch Soldiers. Although his official position granted him some protection against major physical harm, he and other messengers were frequently ransacked and deprived of their valuables before being used as a bargaining chip to obtain ransom money from their families or employers. Comparably, it was not uncommon for soldiers to raid the carts and boats of merchants travelling in the frontier areas, sometimes forcing the local or central governments to organize armed convoys. ${ }^{25}$ The people confronted with the most dangers were however the inhabitants of the frontiers themselves, as they enjoyed neither the protection of a formal function or of a military convoy. These people included for example cattle drivers pasturing their livestock, farmers going to their outlying fields, and commoners visiting their family or attending mass in a neighbouring church.

For these groups, travelling in or across the borderlands entailed the constant risk of physical and financial harm at the hands of bandits, soldiers and sanctioned state officials. But another important consequence of the military contestation of the borderlands was that the physical landscape in which they travelled also changed dramatically. This refers in the first place

\footnotetext{
${ }^{23}$ In his 1601 account of the Revolt the historian Jean-François Le Petit did not introduce the frontier town of Lingen through the usual geographical and historical references, but characterized the city by means of its immense suffering at the frontier and risk of being torn apart by its powerful neighbours: Jean-Francois Le Petit, La grande chroniqve ancienne et moderne de Hollande, Zelande, VVest-Frise, Vtrecht, Frise, Overyssel \& Groeningen, jusques à la fin de I'An 1600, Vol. 1., (Dordrecht: Guillaume Guillemot, 1601), p. 35.

${ }^{24}$ Adriaan M.J de Kraker, "Een staatse strategie in een "uitgestorven" land. Organisatie en ten uitvoerlegging van de brandschat in Vlaanderen, 1585 tot 1604", Bijdragen en Mededelingen betreffende de Geschiedenis der Nederlanden - Low Countries Historical Review 121, (2004), pp. 3-35; Adriaenssen, Staatsvormend geweld; Tim Piceu, Over vrybuters en quaetdoeners. Terreur op het Vlaamse platteland (eind 16de eeuw), (Leuven: Davidsfonds, 2008). For more local cases, see Els Guillemyn, De Vrijbuiters: XVIe-eeuwse guerrillastrijders als voorposten in de 80-jarige oorlog. De Kasselrij Kortrijk in 1584-1593, (Aartrijke: Decock, 1993), pp. 17-19, 79-93. ; Han Verschure, Overleven buiten de Hollandse tuin: Raamsdonk, Waspik, 's Gravenmoer, Capelle, Sprang en Besoijen tijdens de Tachtigjarige Oorlog, (Tilburg: Gianotten, 2004).

25 Piceu, Over vrybuters.
} 
to the inundations that drowned large tracts of land along the frontier. In the 1580's and again after 1621 man-made flooding seriously transformed the frontiers of Flanders, and comparable strategies were followed in Holland, Brabant and elsewhere. ${ }^{26}$ Such inundations were primarily intended to impede the movements of hostile armies, as was for example the case during the famous 1573-1574 siege of Leiden and during the post-Truce sieges of 's Hertogenbosch (1629) and Breda (1637). ${ }^{27}$ Yet the diversion of major waterways equally forced travellers to adapt their normal itineraries: leaving aside the activities of smugglers, most people crossing the borderlands were obliged to take an increasingly fixed set of routes along dikes that had not been pierced or by roads that had not been drowned.

Moreover, the freedom of movement of "regular" travellers such as messengers, merchants and the inhabitants of the borderlands also became more limited because of another type of physical obstructions. The countless new military structures that both sides built in the frontier areas were of even greater importance than the inundations. Prior to the Dutch Revolt the landscape of the Low Countries was already dotted with dozens of fortified cities that served as hubs for an impressive legal and political administrative system, but during the Eighty Years War hundreds of additional sterckten [strongholds], forten [fortresses], redoubten [redoubts] and linies [lines] were added to this. ${ }^{28}$ As with the inundations the primary purpose of these buildings was a military one: to observe and impede the movement of hostile forces and to offer additional protection in the case of an attack. However, by the late 1590 's to early 1600 's these trace-italienne style fortifications were so pervasive that they virtually sealed off the border and could not be ignored by those who travelled the borderlands. ${ }^{29}$ Each of these structures represented a potential checkpoint from where soldiers could observe approaching travellers and from where they could inquire about one's business at the frontiers. And if they considered one of the observed persons

26 Marjolein't Hart, The Dutch Wars of Independence. Warfare and Commerce in the Netherlands, 1570-1680, (London, New York: Routledge, 2014), pp. 106-107; Peter de Cauwer, Tranen van bloed: het beleg van 's-Hertogenbosch en de oorlog in de Nederlanden, 1629, (Amsterdam: Amsterdam University Press, 2007), pp. 74-75.

27 't Hart, The Dutch Wars, pp. 106-107.

28 For a summary in current-day Belgian Flanders, see Westtoer: West-Vlaams provinciebedrijf voor Toerisme en Recreatie, Forten en verdedigingswerken in het Oost- en West-Vlaamse krekengebied. Opgemaakt in opdracht van de Provincies Oost-Vlaanderen en WestVlaanderen. Deel II Inventarisdossier, (s.I.: Provincies Oost- en West-Vlaanderen, 2003). For an overview of early Dutch fortifications, see Frans Westra, Nederlandse ingenieurs en de fortificatiewerken in het eerste tijdperk van de Tachtigjarige Oorlog, 1573-1604, (Alphen aan den Rijn: Rijksuniversiteit Groningen, 1992), pp. 31-55.

${ }^{29}$ About the influence of such trace italienne fortifications across Europe and their relation to territorial control, see Derek Croxton, "A territorial imperative? the Military revolution, strategy and peacemaking in the thirty years war", War in History 5, (1998), pp. 259-260, 266, 274275; S. Kingra Mahinder, "The Trace Italienne and the military revolution during the Eighty Years War, 1567-1648", The Journal of Military History 57, (1993), pp. 434-435. For a wider appraisal, see the contributions in Clifford J. Rogers ed., The Military Revolution Debate. Readings on the Military Transformation of Early Modern Europe, (Boulder Hill, Oxford: Westview Press, 1995) and N. Faucherre, P. Martens and H. Paucot eds., La genèse du système bastionné en Europe/The genesis of the bastioned system in Europe 1500-1550, (Navarrenx: CHA, 2014). 
or groups a potential security risk - or if they simply wanted to ransack or ransom them for money and plunder - these structures likewise formed an ideal base of operations. Although smuggle certainly existed and even flourished in the Habsburg-Dutch borderlands, the new fortifications that emerged along the frontiers literally contained hundreds of spying eyes that observed movement and could set in motion violent actions against any "suspicious" travellers.

The strong militarization of the Habsburg-Dutch borderlands is especially significant because it constituted both a sufficient and a necessary cause for the expanding use of personal passports. Regarding the first, the evertightening network of fortifications and limitations of roads along which people could travel provided an excellent infrastructure to put in place a system of legal border controls. Because it became increasingly hard to travel unseen, the governments of the Habsburg Netherlands and the Dutch Republic eagerly seized the opportunity by requiring all travellers to obtain formal permits or passports personels [personal passports] for border passage - this in addition to the licent they might require for their merchandize. The cities and fortresses along the frontier not only proved excellent locations to check the identity of people who wanted to cross the border and assert one's authority over them, but also for ensuring that they had paid for the right to do so. In this sense the growing military infrastructure of the Eighty Years War sufficed to establish a system of passport controls, as its presence helped the two cash-needy governments to shore up their finances and to make sure that no unwanted persons (confessional agitators, spies, saboteurs, ....) or goods (confessional literature, supplies, arms, gunpowder, ....) crossed the border.

On the other hand, the menacing troops concentrated at the frontiers forced those who wanted or needed to travel to seek as much security as possible. As was highlighted above, even the better protected messengers and merchants still suffered at the hands of the numerous armed actors that operated in the borderlands. This meant that they in turn became the natural supporters of any sort of system that brought them some stability and protection. The inhabitants of the frontiers often found this stability in the form of a declaration of neutrality or by being placed under sauvegarde neither of which will concern us here- but other travellers increasingly relied on the protection the personal passports offered. At first sight this might seem to have amounted to a form of mere "paper" protection, but the legal qualities of the documents - protection offered in the name of the sovereign, signed and sealed by his administration- nevertheless implied that being harmed became much less likely. In this respect the ever-present threat of violence at the frontier formed a necessary condition for the use of passports, simply because no one would apply, let alone pay, for such travel documentation if there was no inherent danger to crossing the border without them. 


\section{The institutionalization of the border during the war: a diversified learning process}

The above-mentioned evolutions can certainly be interpreted as an example of early modern state formation, as they clearly hint at the growth of a physical, legal and economic border administration in function of the interests of the two central governments. However, the risk of such an approach would be that these processes could perhaps be described as too centralized, as if the creation of a more thorough system of border controls was driven by the governments themselves. But in contrast, and as with many other instances of state formation, the two administrations in Brussels/Madrid and The Hague primarily responded to a completely unprecedented situation that had not been created out of their own desire. In fact, at the beginning of the Eighty Years War no one expected that part of the Netherlands would secede and even at to the end of the conflict many continued to argue that the separation should be undone. Crucially, the fact that the governments were confronted with a de facto new territorial boundary meant that they had no fixed plan for dealing with it, something which in turn implied that they constantly needed to adapt and learn from other actors. It would be impossible to provide a complete overview of all of these experiences, but the following examples nevertheless illustrate the width and depth of this governmental learning process, highlighting that the growth of border controls along the Habsburg-Dutch boundary did not only stem from central incentives but often had other origins as well.

\section{Responding to the enemy}

First and foremost, it needs to be stressed that the development of border controls was not a one-sided affair whereby the Dutch Republic and the Habsburg Netherlands operated in a complete vacuum. In fact, both sides frequently reacted to one another when determining which actions to take. Especially in the years leading up to the Twelve Years Truce reciprocity became a key part of the war: if one side moved, the opposing side countered that move with an equal response.

Even when it came to fortification, the conquest of a city or fortress was often followed by the construction of a tegen-fort [counter-fortress] by the retreating party. In 1605 for example the Habsburgs built fort Sint-Frederik and fort Sint-Donaas in Flanders, both intended as counter-fortresses facing Sluis, a city which the Dutch had conquered the year before. ${ }^{30}$ Even at the

30 Westtoer: West-Vlaams provinciebedrijf voor Toerisme en Recreatie, Forten en verdedigingswerken, p. 29. 
very end of the war reciprocity in fortification remained important, as attested by the creation of fort Leopoldus in 1647-1648 as response to the Dutch conquest of Sas-van-Ghent in $1644 .{ }^{31}$ Such fortresses guaranteed that the losing side retained at least some control over the area around the place they had had to abandon, and prevented further enemy incursions launched from that same place. If needed, the tegen-forten could also serve as staging grounds for attempts at recapturing the lost site. However, the result of these building activities was that in many areas the borderlands were not separated by just one but by two lines of defences and check-points, making it even harder for travellers to cross without being seen or being harassed.

Furthermore, reciprocity also implied for the authorities operating at the frontier that any 'precedent' set by the enemy was enough to adapt their own behaviour. In many instances specific measures or legislative actions were taken in response to whatever was happening on the other side. For example, in May 1596 the Estates-General decided that the commanders of the cities of Nijmegen and Bommel and of fortress De Voorn should counter enemy raiders or lopers on their turf by better executing earlier instructions regarding these intruders. As the assembly indicated, this order was a direct response to a letter sent by the Habsburg commander of Grave, who had demanded that the tenants of the religious properties and fiefs in Dutch Isendoren and Echtelt paid him his due. ${ }^{32}$ And a month later, the EstatesGeneral informed the Count of Hohenlo that he was allowed to write to the Habsburg-controlled city of 's-Hertogenbosch that the surrounding Meijerij would be raided if the Habsburgs continued to demand payments from the nearby county of Buren. ${ }^{33}$ In both cases, cross-border actions from the Habsburg side were deemed sufficiently annoying to provoke a measured military or legal response.

Moreover, especially when local or intermediary forces demanded retribution for enemy precedents, the level of reciprocity could also be quite detailed - even small precedents could be enough to incite a reaction - either by equal or larger counter-actions. In March 1598 the Dutch Council of Guelders and Zutphen requested the assistance of the Estates-General, for instance. Apparently, the enemy had started to steal the horses of the towships on the Meuse, whilst the soldiers of the Republic did not bother the shippers of Habsburg-held Venlo and Grave. Stadholder Maurits and the Council of State proposed that the defences on the Meuse should be increased in order to prevent future problems, but the Admiralty of Rotterdam believed that an eye for an eye would be more effective: the Estates-General should

\footnotetext{
31 Westtoer: West-Vlaams provinciebedrijf voor Toerisme en Recreatie, Forten en verdedigingswerken, p. 66.

32 Resolution regarding the contributions in Isendoren and Echtelt, 20/05/1596: N. Japikske, Resolutiën der Staten-Generaal, 1576-1609. Negende Deel, 1596-1597, ('s-Gravenhage, 1929), p. 17. On pp.19-21 a similar order regarding Bommel.

33 Resolution regarding the contributions in Buren, 20/05/1596: Japikske, Resolutiën der Staten-Generaal, 1576-1609. Negende Deel, 1596-1597, p. 21.
} 
break quarter with the Habsburg forces along the river and hang any offenders they captured as stroomschenders [violaters of the stream]. ${ }^{34}$ Similarly, in May 1598 Mayor De Beyer of Nijmegen requested to collect double taxes on the horses and chariots travelling across the Land van Peel and the Overkwartier because the Habsburg garrison of Grave did the same for those in the Rijk van Nijmegen. ${ }^{35}$ In this case the central authorities however decided to hold back on the local demands: the Dutch Council of State declared that no violent actions were to occur in the Overkwartier, unless the incursions from Grave became structural. ${ }^{36}$

\section{Suggestions from subjects}

Secondly, another great source of learning for both governments was their own subjects. On many occasions local border practices or innovations were picked up by the central authorities and expanded to the rest of the borderlands, or new policies were suggested by people with a first-hand experience of 'life at the frontiers'. The career of Johan Moryn is exemplary in this respect. Sometime around 1594-1595 Moryn, an inhabitant of Antwerp, complained to the Habsburg government that due to the leniency of the customs officers people coming from 'rebel lands' could enter the city without a personal passport, disregarding the placards that forbade this practice. In Moryn's opinion, the prime problem with these daily offenses was that for each passport not issued the Habsburg King missed six florins of droit de sceau [right of seal], amounting to a significant financial loss. As he continued, what caused these offenses was the fact that there only worked a controleur-general des passeports des marchandises [inspector-general of passports for merchandize] in Antwerp, ${ }^{37}$ and not a controleur-general des passeports personnels [inspector-general of personal passports].

Following Moryn's advice, the Habsburg authorities created the latter function on 30 December 1595, as this would hopefully both reinforce royal authority and increase revenue. ${ }^{38}$ As a reward for pointing the Crown towards this undesired situation, the government also granted Moryn what had presumably been his objective all along: his appointment as the first holder of the lucrative new office he himself had suggested. Moryn was ordered to keep an eye on the traffic of individuals via the ports and rivers of Antwerp,

\footnotetext{
34 Resolution regarding retorsion along the Meuze, 19/03/1598: Japikske, Resolutiën der Staten-Generaal, 1576-1609. Tiende Deel, 1598-1599, 15.

35 Resolution regarding the contributions in Nijmegen, 01/05/1598: Japikske, Resolutiën der Staten-Generaal, 1576-1609. Tiende Deel, 1598-1599, p. 21.

36 Resolutions regarding the contributions in Nijmegen, 07/05/1598 and 08/06/1598: Japikske, Resolutiën der Staten-Generaal, 1576-1609. Tiende Deel, 1598-1599, pp. 21, 23.

37 The first Habsburg regulations for trade by licent had been put into place on 6 December 1592 and 20 March 1593: Bindoff, The Scheldt Question, p. 90.

38 Appointment of Johan Moryn as controleur-general des passeports, 30/12/1595: AGR Papiers d'Etat et de l'Audience, 1137/3 (5).
} 
Sas-van-Gent, and Grave, could charge four patars for each passport he checked and registered, and was allowed to keep one third of the fines he collected. ${ }^{39}$ Three years later his appointment as controleur-general des passeports personnels was renewed, this time for the entire province of Brabant. Moryn was again ushered to keep track of everybody who came from and went to Holland and Zeeland, and a number of locations were identified as key points for fraudulent border passage: fort Ordam near Zevenbergen, the city of Grave along the Meuse and fort Artsen on the Rhine. Moreover, and even though his first appointment had already included measures to inform the Provincial Councils of Flanders, Brabant and Guelders of his new role, Moryn's renewed commission also mentioned that the advocate-fiscal of Brabant should no longer occupy himself with controlling the passports, hinting at a potential earlier conflict of (financial) interest between these two officers. ${ }^{40}$ And as an important addendum to Moryn's story, after the Twelve Years Truce the Habsburgs likewise continued to improve their controlsystem by copying practices from local officers. In 1626 the Brussels government decided that one ecu or three florins hooftgelt [money per 'head'] would be added to the six florins of the droit the sceau already levied on each passport, based on the fact that this special measure delivered an additional 12.000 florins annually to the collector of the border crossing near Ordam. ${ }^{41}$

\section{Discussions with subjects and other subordinates}

Thirdly, not all contacts between the authorities and their subjects went well. Often people tred to avoid, bend or break the controls put in place by the two governments, actions that frequently attracted a counteraction. In regard to their experiences with subordinates, the learning process of the administrations in Brussels/Madrid and The Hague were thus not solely benign but were often fraught with tension. Nevertheless, such confrontations were also an important opportunity to better understand the differences between ordering a policy and successfully implementing it.

The import of Dutch and German horses in Habsburg Brabant stands out as a particularly interesting case. Firstly, horses were part of the 'strategic goods' that generated product-specific legislation, placing them at the same level as iron, grain and other corn crops, hops, wine, beer, alum, cloth, wool, saltpetre, powder and ammunition. Secondly, the nine regulations regarding the Brabantine horse trade issued by Brussels between October 1608 and

39 Appointment of Johan Moryn as controleur-general des passeports, 30/12/1595: AGR Papiers d'Etat et de l'Audience, 1137/3 (5).

40 Appointment of Johan Moryn as controleur-general des passeports, 29/3/1598: AGR Papiers d'Etat et de l'Audience, 1137/3 (5). Moryn was again appointed in March 1601: Appointment of Johan Moryn as controleur-general des passeports, 24/3/1601: AGR Papiers d'Etat et de l'Audience, 1137/3 (5).

${ }^{41}$ Specification of sauvegarde and passport regulations, 20/8/1621: AGR Papiers d'Etat et de l'Audience, 1137/3 (3). 
August 1632 related specifically to the context of the Eighty Years War: a tax on horses introduced in 1508 had remained uncollected since $1552 .{ }^{42}$ Because of its revival during the war the discussions surrounding this tax were particularly intricate and related closely to the establishment of the new licenten-system. Thirdly, the discussions over these rules not only involved actors from the Low Countries but also German importers, highlighting that managing the Habsburg-Dutch frontier was not always a bilateral affair but sometimes involved third parties as well. And fourth and lastly, the Habsburg regulation for horses nicely complements Wilhelmina Gijsbers' comments on the Dutch regulation for the trade of cattle, as she observed that similar bargaining mechanisms applied to the im- and export of this livestock. ${ }^{43}$

Starting with the first regulation, in October 1608 the Archdukes Albert and Isabella forbade the import of all horses from Zeeland and Holland into Brabant except after the payment of four guilders licentgeld to the Habsburg licent-officer in the frontier city of 's-Hertogenbosch. All other inroads into Brabant were explicitly forbidden and a whole range of practical regulations was put in place to enforce these rules. One prescription for example specified that no animals could be stabled in Brabantine cities before the original licentbrief from 's-Hertogenbosch had been inspected and signed by the local authorities. However, because it could be claimed (correctly or not) that the local officer had not been home when the horses arrived, merchants were allowed to show their credentials to the licentmeester's neighbours. It was also declared that if unlicensed horses were found in the stables of a private person, this person would be considered equally liable and would be fined 25 stuivers for each horse. ${ }^{44}$ Widening the scope of the people involved in the illicit horse trade, the placard also complained about the "major ruses, practices and deceptions" committed by people living in the countryside, and of the use of neutral (German) territories as a base for importing unlicensed Dutch horses. As a solution to these practices, the placard ordained that all imported horses were required to have a licentbrief, regardless of their origin. 45

Similar complexities continued to apply during the Twelve Years Truce. ${ }^{46}$ On 11 August 1609 the Archdukes confirmed that, despite the end of hostilities, licenten still needed to be paid for imported horses, an order they

\footnotetext{
42 Gheret, "Le produit", pp. 72-73.

43 Wilhelmina Maria Gijsbers, Kapitale ossen. De internationale handel in slachtvee in Noordwest-Europa (1300-1750), (Hilversum: Uitgeverij Verloren, 1999).

44 Placard regarding the import of horses in Brabant, 10/10/1608: Anselmo, Placcaeten, ordonnantien, Vol. 1, pp. 383-386.

45 "Groote listen, practycken ende bedroch": Placcard concering the import of horses from Holland and Zeeland in Brabant, 10/10/1608: Anselmo, Placcaeten, ordonnantien, Vol. 1, pp. 383-386.

${ }^{46}$ For another case involving livestock, see Letter from the Estates-General regarding the trade in cattle and horses, 16/06/1609: AGR Papiers d'Etat et de l'Audience, 1502/2; Letter from the Estates-General regarding the trade in cattle and horses, 20/06/1609: AGR Papiers d'Etat et de I'Audience, 1502/2.
} 
repeated two weeks later. ${ }^{47}$ Comparable legislation followed in August 1612, February 1615 and May 1619. ${ }^{48}$ These repetitions quickly prompted conflicts between local officers and traders. For instance, the placard of 11 August 1609 instructed the licentmeesters to keep a strict eye on the FlemishBrabantine borderlands, as it had been observed that the merchants held illegal horse fairs in pastures near the rivers Scheldt and Dijle. Apparently, the traders also worked closely together in order to avoid being checked: sometimes the horses of a merchant without a licent were imported by one with a permit, in other cases two merchants started a discussion with the Habsburg officers so a third one could quietly slip past.

After 1621 the import ban on Dutch horses was again renewed, albeit in a less strict form. The licentbrief no longer needed to be obtained in 'sHertogenbosch but could now be legally bought in other Habsburg cities as well. This made commerce much easier for the merchants, but in order to prevent the fraudulent selling of horses along the road it was still required to travel to these cities following a direct itinerary. As a second measure, fraud with horses supposedly raised in neutral places remained forbidden, but if a proper certificate of origin could be provided (containing the age, colour and markings of each animal) paying licentgeld was no longer required. In order to avoid discussions during the controls this certificate needed to be drafted by a sworn notary of the neutral place of origin and, when written in German, should be translated into French. If, however, there was disagreement over the validity of a particular certificate, the merchant or transporter was allowed to provisionally pay licentgeld, return to the place where he had obtained his certificate, renew the proof of origin, and travel back to the Habsburg Netherlands to re-collect his deposit. On their part, the licenten-officers and controleurs could levy no charge for the inspection of these documents, as they indeed frequently requested additional fees for their services. ${ }^{49}$

Despite all these measures, by April 1627 new legislation regarding the certificates from neutral lands was issued at the instigation of the merchants and magistrate of Maastricht. As the city and its commercial powers claimed, the Habsburg officials found it entirely impossible to check whether a horse had really been raised in neutral lands or if it merely had been bought there from a Dutch horse breeder. In response, Governess-General Isabella relaxed the regulations for the certificates to include the latter category, making it again much easier for the merchants to sell and buy animals with a

\footnotetext{
47 Placard regarding the horse trade, 11/08/1609: Victor Brants ed., Receuil des ordonnances des Pays-Bas. Règne d'Albert et Isabelle, 1597-1621, Vol. 2. (Brussels: Goemaere, 1909), pp. 12-14; Placard regarding the horse trade, 27/08/1609: Brants, Recueil des Ordonnances, Vol. 2, pp. 14-15.

48 Placard regarding the horse trade, 14/08/1612: Brants, Recueil des Ordonnances, Vol. 2, pp. 145-147; Placard regarding the horse trade, 12/02/1615: Brants, Recueil des Ordonnances, Vol. 2, pp. 243-246; Placard regarding the horse trade, 17/06/1619: Brants, Recueil des Ordonnances, Vol. 2, pp. 440-441.

49 Placard regarding the import of horses in Brabant, 22/01/1622: Placcaeten, ordonnantien, Vol. 1, pp. 386-391. Repeated on 22/12/1626: Placcaeten, ordonnantien, Vol. 1, pp. 391-392.
} 
supposedly German origin. ${ }^{50}$ However, two years later this was again deemed an inefficient measure, and the Habsburg authorities renewed the obligation to pay licentgeld for all horses coming from neutral lands. ${ }^{51}$

Another trick against which the government had to arm its licent-officers was the claim that any unlicensed horses discovered were not destined to be sold but in fact simply belonged to a private person in the Habsburg Netherlands who wanted them transported between his/her domains. This strategy was already acted against by the 1608 placard, ${ }^{52}$ but seems to have been particularly problematic in the late 1620s. Just as the placard of April 1627 had been issued as a bottom-up request of the city of Maastricht, on 6 August 1629 a new ordinance was published at the instigation of Jacques Doncq and Adriaen van Drunen, licentpachters [licence-tenants, officers whom had paid the Council of Finances for the right to collect the licentgeld in a particular area] in 's-Hertogenbosch. ${ }^{53}$ As these two officers complained, many transporters refused to pay the required licenten. Apparently, whenever the officers checked the importers of horses, these people claimed that they did not need to pay licentgeld because Doncq and van Drunen could not prove that they really intended to sell the animals. If the two licentpachters subsequently traced the buyers of these horses, these persons also claimed that they did not need to pay licentgeld on the ground that the horses had already been imported by the sellers. Because the placards applied only to the category of 'imported horses destined for trade', merchants could easily claim that their animals were either not imported by them or not destined for trade. ${ }^{54}$

Besides providing an insight into the frustrating nature of being an early modern border officer, the case of the Brabantine horse trade demonstrates the extent to which merchants knew how to confront, handle and mould the available legal border structures. In this case as in others, regulating crossborder trade during the Eighty Years War was not simply a matter of imposing the will of the central authorities but reflected a dialogue with numerous discussants that had an interest in traversing the frontier. Even though the government always had the last word in terms of the actual legislation issued, the practical enforcement of passage laws was often much more troubled

\footnotetext{
50 Placcard regarding the import of horses from Westphalia and other neutral lands, 30/04/1627: Placcaeten, ordonnantien, Vol. 1, pp. 392-393.

51 Placcard regarding the import of horses, 22/01/1629: Placcaeten, ordonnantien, Vol. 4, pp. 73-77.

52 Placard regarding the import of horses in Brabant, 10/10/1598: Placcaeten, ordonnantien, Vol. 1, 383-386.

53 The practice whereby the office of licentmeester and/or controlleur was verpacht [leased] for a short period actually formed the most common appointment policy. Candidates were usually found in the domanial administration of the King, the legal practice, city magistrates or indeed the commercial world itself: Gheret, "Le produit", pp. 48-9.

${ }^{54}$ A similar problem existed on the Dutch side with regard to livestock, as the Estates-General distinguished between animals that would be pastured in the Republic or in neutral and hostile lands. However, livestock destined for the former frequently ended up in the latter: Gijsbers, Kapitale ossen, p. 53.
} 
than anticipated and necessitated constant adaptations in the available preand proscriptions. Effectively, the attempts at (controlling) border passage demonstrate the extent to which the two governments needed to learn from each other and from their own subjects.

\section{Conclusion}

The above few pages have discussed the growth and institutionalization of border controls during the Eighty Years War, stressing that this development should not be seen as an example of centralized state formation. Instead, the examples mentioned demonstrate that the governments in Brussels/Madrid and The Hague in many ways themselves needed to adapt to this new and unexpected territorial fracture. This article could of course not discuss all strategies by which the two administrations did do, nor could it provide a complete overview of all the military and legal aspects of the Habsburg-Dutch border controls, but the three examples here provided clarify some of the more important aspects of the governmental learning curve. In the first place it was highlighted that many strategies of border management were formulated in response to what was happening on the other side. The authorities in both the Habsburg Netherlands and in the United Provinces were engaged in a bilateral relation whereby many policies and concrete actions were tailored in reaction to what the enemy was doing. Secondly, the two governments did not determine what their border controls would look like in isolation from their subjects. People living at the frontier, such as Johan Moryn, could offer their view on how the border should be handled and benefitted from doing so. Thirdly, in other cases the Habsburg and Dutch authorities were forced to respond to the actions of less cooperative subjects and other subordinates who tried to maintain cross-border activities. Legislation regarding the boundary constantly needed to be adapted to smuggling activities, attempts at tax avoidance and clever legal reasoning on the part of the merchants discussed. Combined, these three types of learning processes illustrate that the formation and implementation of border controls during the Eighty Years War did not follow a clearly outlined plan, but often happened in a largely ad hoc and haphazard manner. 
Documentary Sources:

Algemeen Rijksarchief/Archives General du Royaume, Brussels (hereafter AGR), Conseil d'Etat, nr. 1592.

AGR Papiers d'Etat et de I'Audience, nr. 1137/3 (3).

AGR Papiers d'Etat et de I'Audience, nr. 1137/3 (5).

AGR Papiers d'Etat et de l'Audience, nr. 1502/2.

Bibliography:

Primary Sources:

Anselmo 1648: Antonium Anselmo, Placcaeten, ordonnantien, landt-chartres, blyde-incomsten, privilegien, ende instructien, by den Princen van dese Neder-landen aen de Inghesetenen van Brabandt, Vlaenderen, ende andere provincien, t'sedert t'Iaer M.CC.XX., vol. 1, (Antwerp: Hendrick Aertssens, 1648).

Brants 1909: Victor Brants ed., Receuil des ordonnances des Pays-Bas. Règne d'Albert et Isabelle, 1597-1621, Vol. 2., (Brussels: Goemaere, 1909).

Christyn 1664: Jan Baptiste Christyn, Placcaeten, ordonnantien, landtchartres, blyde-incomsten, privilegien, ende instructien, by den Princen van dese Neder-landen aen de Inghesetenen van Brabandt, Vlaenderen, ende andere provincien, t'sedert t'Iaer M.CC.XX., Vol. 3, (Brussels: Huybrecht Anthoon Velpius, 1664).

Japikske 1929: N. Japikske, Resolutiën der Staten-Generaal, 1576-1609. Negende Deel, 1596-1597, ('s-Gravenhage: Martinus Nijhoff, 1929).

Japikske 1930: N. Japikske, Resolutiën der Staten-Generaal, 1576-1609. Tiende Deel, 1598-1599, ('s-Gravenhage: Martinus Nijhoff, 1930).

Le Petit 1601: Jean-Francois Le Petit, La grande chroniqve ancienne et moderne de Hollande, Zelande, VVest-Frise, Vtrecht, Frise, Overyssel \& Groeningen, jusques à la fin de I'An 1600, Vol. 1., (Dordrecht: Guillaume Guillemot, 1601). 
Secondary sources:

Adriaenssen 2007: Leo Adriaenssen, Staatsvormend geweld. Overleven aan de frontlinies in de meierij van Den Bosch, 1572-1629, (Tilburg: Stiching Zuidelijk Historisch Contact, 2007).

Bindoff 1945: Stanley Bindoff, The Scheldt Question to 1839, (London: George Allen \& Unwin, 1945).

Cauwer 2007: Peter de Cauwer, Tranen van bloed: het beleg van 'sHertogenbosch en de oorlog in de Nederlanden, 1629, (Amsterdam: Amsterdam University Press, 2007).

Croxton 1998: Derek Croxton, "A territorial imperative? The Military revolution, strategy and peacemaking in the thirty years war", War in History 5, (1998), pp. 253-279.

Dorban 1998 : Michel Dorban, ed. Douane, commerce et fraude dans le sud de l'espace Belge et Grand-Ducal au XVIIIe siècle. Travaux d'étudiants synthétisés par Christien Piraux, (Louvain-la-Neuve: Bruylant-Academia, 1998).

Enthoven 1995: Victor Enthoven, "De ondergang van de Nederlandse handelssuprematie. Fiscale maatregelen en maritieme machtsmiddelen in de $17^{\text {de }}$ eeuw", in De Republiek tussen zee en vasteland. Buitenlandse invloeden op cultuur, economie en politiek in Nederland, 1580-1800, eds. Karel Davids, Marjolein 't Hart, Henk Kleijer and Jan Lucassen, (Leuven, Apeldoorn: Garant, 1995), pp. 249-271.

Enthoven 1996: Victor Enthoven, Zeeland en de opkomst van de Republiek. Handel en strijd in de Scheldedelta, c. 1550-1621, (Leiden: Luctor et victor, 1996).

Enthoven 2007: Victor Enthoven, "Een duivels dilemma: Zeeland en de beheersing van de Schelde, 1572-1609", in De Scheldedelta als verbinding en scheiding tussen Noord en Zuid, 1500-1800, eds. Maurits Ebben and Simon Groenveld, (Maastricht: Shaker Publishing, 2007), pp. 27-49.

Faucherre 2014: N. Faucherre, P. Martens and H. Paucot eds., La genèse du système bastionné en Europe/The genesis of the bastioned system in Europe 1500-1550, (Navarrenx: CHA, 2014).

Gheret 1970: Daniel Gheret, "Le produit des licences et autres impôts sur le commerce extérieur dans les Pays-Bas espagnols (1585-1621)", in Recherches sur I'histoire des finances publiques en Belgique, Tome II, Acta Historica Bruxellencia 2, eds. M.-A. Arnould, J. Craeybeckx and H. Hasquin, 
(Brussels: Institut d'histoire de I'Université Libre de Bruxelles, 1970), pp. 43122.

Gijsbers 1999: Wilhelmina Maria Gijsbers, Kapitale ossen. De internationale handel in slachtvee in Noordwest-Europa (1300-1750), (Hilversum: Uitgeverij Verloren, 1999).

Graaf 2004: Ronald De Graaf, Oorlog, mijn arme schapen. Een andere kijk op de Tachtigjarige Oorlog 1565-1648, (Franeker: Van Wijnen, 2004).

Grapperhaus 1986: F.H.M. Grapperhaus, Convoyen en licenten, (Zutphen, Deventer: De Walburg Pers/Kluwer, 1986).

Guillemyn 1993: Els Guillemyn, De Vrijbuiters: XVIe-eeuwse guerrillastrijders als voorposten in de 80-jarige oorlog. De Kasselrij Kortrijk in 1584-1593, (Aartrijke: Decock, 1993).

Israel 1977: Jonathan I. Israel, "A conflict of Empires: Spain and the Netherlands, 1618-1648", in Israel, Empires and Entrepots, pp. 1-42. First printed in Past and Present 76, (1977), pp. 34-74.

Israel 1988: Jonathan I. Israel, "España, los embargos españoles y la lucha por el dominio del comercio mundial, 1585-1648", Revista de Historia Naval 23, (1988), pp. 89-105.

Israel 1989: Jonathan I. Israel, Dutch Primacy in World Trade, 1585-1740, (Oxford: Clarendon Press, 1989).

Israel 1990: Jonathan I. Israel, Empires and Entrepots. The Dutch, the Spanish Monarchy and the Jews, 1585-1713, (London, Ronceverte: The Hambledon Press, 1990).

Israel 1995: Jonathan I. Israel, The Dutch Republic. Its Rise, Greatness, and Fall 1477-1806, (Oxford: Clarendon Press, 1995)

Jong 2005: Michiel de Jong, Staat van oorlog: wapenbedrijf en militaire hervorming in de republiek der Verenigde Nederlanden, 1585 - 1621, (Hilversum: Verloren, 2005).

Kernkamp 1931: J.H. Kernkamp, De handel op den vijand, 1572-1609, Vol. 1, (Utrecht, 1931).

Kingra 1993: S. Kingra Mahinder, "The Trace Italienne and the military revolution during the Eighty Years War, 1567-1648", The Journal of Military History 57, (1993), pp. 431-466. 
Kraker 2004: Adriaan M. J de Kraker, "Een staatse strategie in een "uitgestorven" land. Organisatie en ten uitvoerlegging van de brandschat in Vlaanderen, 1585 tot 1604", Bijdragen en Mededelingen betreffende de Geschiedenis der Nederlanden - Low Countries Historical Review 121, (2004), pp. 3-35.

Leemans 1981: W.F. Leemans, De grote Gelderse tollen en de tollenaars in de 18 e en het begin der 19de eeuw. Een bijdrage tot de geschiedenis van de Rijnhandel, (Arnhem: De Walburg Pers, 1981).

Moureaux 1966: P. Moureaux, "Un organe peu connu du gouvernement des Pays-Bas autrichiens: le Bureau de régie des droits d'entrée et de sortie", Belgisch Tijdschrift voor Filologie en Geschiedenis/ Revue Belge de Philologie et Histoire 44, (1966), pp. 479-499.

Piceu 2008: Tim Piceu, Over vrybuters en quaetdoeners. Terreur op het Vlaamse platteland (eind 16de eeuw), (Leuven: Davidsfonds, 2008).

Prak 2005: Maarten Prak, The Dutch Republic in the Seventeenth Century: The Golden Age, (Cambridge: University Press, 2005).

Rogers 1995: Clifford J. Rogers ed., The Military Revolution Debate. Readings on the Military Transformation of Early Modern Europe, (Boulder Hill, Oxford: Westview Press, 1995).

Stols 1971: Eddy Stols, De Spaanse Brabanders of de handelsbetrekkingen der zuidelijke Nederlanden met de Iberische Wereld, 1598-1609, (Brussels: Koninklijke Vlaamse Academie voor Wetenschappen, Letteren en Schone Kunsten van België, 1971).

Stradling 1980: R.A. Stradling, "The Spanish Dunkirkers, 1621-48: A Record of Plunder and Destruction", Tijdschrift voor Geschiedenis 93, (1980), pp. 541-558.

T'Hart 1993: Marjolein 't Hart, The making of a bourgeois state: war, politics and finance during the Dutch revolt, (Manchester: Manchester University Press, 1993).

T'Hart 1996: Marjolein 't Hart, "The merits of a financial revolution: public finance, 1550-1700", in A Financial history of The Netherlands, eds. Marjolein 't Hart, Joost Jonker and Jan Luiten van Zanden, (Cambridge: Cambridge University Press, 1996), pp. 11-35.

T'Hart 2014: Marjolein't Hart, The Dutch Wars of Independence. Warfare and Commerce in the Netherlands, 1570-1680, (London, New York: Routledge, 2014). 
Verschure 2004: Han Verschure, Overleven buiten de Hollandse tuin: Raamsdonk, Waspik, 's Gravenmoer, Capelle, Sprang en Besoijen tijdens de Tachtigjarige Oorlog, (Tilburg: Gianotten, 2004).

West 2005: Virginia West Lunsford, Piracy and Privateering in the Golden Age Netherlands, (New York: Palgrave Macmillan, 2005).

Westra 1992: Frans Westra, Nederlandse ingenieurs en de fortificatiewerken in het eerste tijdperk van de Tachtigjarige Oorlog, 1573-1604, (Alphen aan den Rijn: Rijksuniversiteit Groningen, 1992).

Westtoer 2003: West-Vlaams provinciebedrijf voor Toerisme en Recreatie, Forten en verdedigingswerken in het Oost- en West-Vlaamse krekengebied. Opgemaakt in opdracht van de Provincies Oost-Vlaanderen en WestVlaanderen. Deel II Inventarisdossier, (s.l.: Provincies Oost- en WestVlaanderen, 2003).

Zwitser 1982: H.L. Zwitser, "Het quotenstelsel onder de Republiek der Verenigde Nederlanden", Mededelingen van de Sectie Militaire Geschiedenis Landmachtstaf 5, (1982), pp. 1-54. 